\title{
PERINATAL MENTAL HEALTH: LABELS AND STIGMAS
}

Prof. Dr. Juan Pablo-Bellotti, MD, MSc, MSc, PhD, Prof. Lic. Giselle Corti, BSc, MSc

\section{iversidad del Museo Social Argentino, Buenos Aires, Argentina}

\section{OBJECTIVES}

To break with the paradigm of stigmatizing pregnant/puerperal women with comorbid psychiatric disorders, the psychiatrists who treat them and the psychotropic medication they are prescribed.

\section{INTRODUCTION}

Stigma is caused by fear, ignorance, prejudicial attitudes and discriminating behavior directed towards minorities as is the case of perinatal psychiatric women. Self-stigma is the internalization of perceived stigma and a result of derogative labels, social exclusion and isolation.

\section{MATERIALS AND METHODS \\ Prospective, longitudinal, despriptive case series of} pregnant/puerperal women who consulted between 2018-2019 to the author's medical office and required psyco-pharmacological treatment. Patients who had signed a written informed consent and completed the post hoc questionnaire and attended to interviews were included $(n=50)$.

\section{RESULTS}

Common reports among patients:

- stigma and self-stigma of having a mental illness independently of the diagnoses, severity, evolution, prognosis $(n=50)$.

- stigma to psychotropic drugs held by physicians, due to the false belief they are $100 \%$ teratogenic. MDs thereby tried, without success, to suspend the pharmachologic treatment $(n=45)$ or indicate unjustified abortions $(n=5)$.

- stigma to psychiatrists who were judged as medieval merchants that have financial and other interests with pharmaceutical industries $(n=35)$,

obstetric violence and violation of the principles of nonmaleficence and autonomy $(n=3)$.

- intrusiveness of social work services and fear of loss of custody of and contact with their children $(n=12)$

\begin{tabular}{|c|c|}
\hline Item & Results \\
\hline Median Age & 32 (range: $21-44$ ) \\
\hline $\begin{array}{l}\text { Psychiatric Pre- } \\
\text { existing } \\
\text { Pathology } \\
(85 \%)\end{array}$ & $\begin{array}{l}20 \% \text { Depression } \\
40 \% \text { Anxiety } \\
20 \% \text { Post traumatic Stress } \\
10 \% \text { Chronic Schizophrenia } \\
10 \% \text { Bipolar Disorder }\end{array}$ \\
\hline $\begin{array}{l}\text { De Novo } \\
\text { Pathology } \\
(15 \%)\end{array}$ & $\begin{array}{l}\text { 70\% Anxiety } \\
30 \% \text { Depression }\end{array}$ \\
\hline $\begin{array}{l}\text { Gestational } \\
\text { Trimester }\end{array}$ & $\begin{array}{l}\text { First } 80 \% \\
\text { Second } 20 \% \\
100 \% \text { medicated until the } 3^{\circ} \text { Trimester and } \\
\text { Puerperium }\end{array}$ \\
\hline Complications & $\begin{array}{l}\text { Mother: None } \\
\text { Neonate: } 2 \text { premature births unrelated with } \\
\text { psycotropic drug administration }\end{array}$ \\
\hline
\end{tabular}

\section{Stand up aftalnst st:Gne}

No Health without Mental Health
Smile and stop

being a disturbed freak! Do it for your child!

You are such an attention-seeking nutter

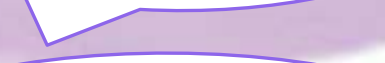

Quit being such a psycho!

Crazy woman like you cannot be a good mum

Women with mental issues should be sterilized
The imposed belief mothers with mental needs are unable to nurture their children, has detrimental effects on their already depleted selfesteem. Some react to such negative stereotypes by:

-denying their condition, with excacerbation of psychiatric symptoms and non-compliance with medical treatment plans $(n=0)$

-feeling an excessive pressure to be compliant with medical treatment plans, undergoing their pregnancies with fear:

- to the trauma of psychiatric hospitalization $(n=50)$,

- that if they react negatively to their children during the day-to-day stresses of parenting, then their mental health symptoms would be blamed $(\mathrm{n}=50)$,

- to the community's lack of empathy and respect thus concealing everything from people $(n=50)$,

- of close family members who commonly undermine and threat them. Or just replace them as the responsible caregiver for their child leaving mothers feeling disempowered and devalued in their roles, and even instigating them to commit suicide $(n=2)$.

- of partners who tend to be unsupportive and unsympathetic to their mental health needs $(n=40)$. Indeed, some women fear that if they broke up the relationship with the father, then they would lose residency of their children simply because of their psychiatric diagnosis $(n=17)$

\section{COMMENTS}

Contrary to the image portrayed by research, most women with mental health needs are good enough parents and the majority place precedence on having a good relationship with the child. Yet, most practitioners fail to assess the strengths and abilities of parents having a presumption of their inadequacy until proved otherwise, as our experience suggests.

\section{CONCLUSIONS}

Perinatal healthcare provision can be more effective when it is built on a model that promotes shared decision-making and a sense of trust with shared responsibility. It is essential to understand that there is no health without psychic well-being, and that most psychotropic drugs can be safely used during pregnancy/lactation to neuroprotect both the mother and fetus/infant. Reinforcing the potential for mental health awareness campaigns and transdisciplinary approaches are needed to eliminate labels and stigma, and to treat perinatal psychiatric patients with respect.

\section{REFERENCES}

1. Somers V. Schizophrenia: the impact of parental illness on children. Br J Soc Work. 2007;37:1319-1334

2. Downey G, Coyne JC. Children of depressed parents: an integrative review. Psychol Bull. 1990;108:50-76.

3. Taylor CG, Norman DK, Murphy JM, et al. Diagnosed intellectual and emotional impairment among parents who seriously mistreat their children: prevalence, type and outcome in a court sample. Child Abuse Negl. 1991;15:389-401.

4. Falcov A. Fatal Child Abuse and Parental Psychiatric Disorder. Working Together, Part 8 Reports.Department of Health ACPC Series, no. 1. London, UK: HMSO; 1996.

5. Nicholson J, Sweeney EM, Geller JL. Focus on women: mothers with mental illness: I. The competing demands of parenting and living with mental illness. Psychiatr Serv. 1998;49:635-642.

6. Busch A, Redlich AD. Patients' perception of possible child custody or visitation loss for non-adherence to psychiatric treatment. Psychiatr Serv. 2007;58:999-1002. 